\title{
PROBLEMS OF CROSS-BORDER COOPERATION BETWEEN POLAND AND THE KALININGRAD OBLAST OF THE RUSSIAN FEDERATION
}

\author{
TAdeusz PaLmowsKi \\ Gdańsk University, Regional Development Geography Department, Gdańsk, Poland
}

Manuscript received July 16, 2010

Revised version November 22, 2010

\begin{abstract}
Palmowski T., Problems of cross-border cooperation between Poland and the Kaliningrad Oblast of the Russian Federation. Quaestiones Geographicae 29(4), Bogucki Wydawnictwo Naukowe, Poznań 2010, pp. 75-82, 1 table. DOI 10.2478/v10117-010-0033-2, ISBN 978-83-62662-30-2, ISSN 0137-477X.
\end{abstract}

ABSTRACT. Thanks to the opening of Europe to Kaliningrad and Kaliningrad to Europe, this region has been given an opportunity to gradually break the isolation which was the primary reason for its peripheral position. The enlargement of the Schengen Area complicated its relations and weakened cross-border cooperation with Poland. Further cross-border cooperation trends, though facing various barriers, may lead to improving the state of the natural environment in the Polish-Russian transborder region, joint planning of its development, growing mutual contacts, and making the populations living on both sides of the border more familiar with each other.

Kaliningrad's future also requires sustainable economic, ecological, social and political development. The working out of new principles of model cooperation between the EU and Russia may significantly stimulate the economy in the Polish-Russian cross-border areas. The mainstream options for opening Kaliningrad to regional cooperation can be an important step towards full integration of Baltic Europe.

KEY wORDS: cross-border cooperation, Kaliningrad Oblast

Tadeusz Palmowski, Institute of Geography, Regional Development Geography Department, Gdańsk University, ul. Bażyńskiego 4, 80-952 Gdańsk, Poland; e-mail: geotpl@univ.gda.pl

Following 1990, the process of reinstating historical relations began with new economic and cultural relations developing around the Baltic Sea. Cooperation and integration processes spread across many spheres of social, economic and political life, assuming various forms; both institutional, governmental bi- and multiparty forms as well as nongovernmental activities at various levels and among a range of environmental groups. The integration of Baltic Europe develops as a transnational political and institutional network. The dynamic development of transborder relations has triggered the downfall of barriers and prejudice and helped to build up official and unofficial interpersonal relations, especially between members of local societies.

The Kaliningrad Oblast is a Russian exclave lying by the Baltic Sea. Until 1991 it was closed to foreigners and completely isolated from the West due to its strategic role as a base of the Soviet Union navy as well as the land and air forces. As the westernmost and strongly militarised part of the Russian Soviet Federative Socialist Republic (RSFSR), separated by the territories of republics being part of one federation, until the late 1980s it remained a taboo subject, as if nonexistent on 
political maps. The situation of the area changed dramatically at the turn of the 1980s and ' 90 s. The disintegration of the Soviet Union made a region which for decades was a closed military base the subject of political discussions. With Lithuania gaining independence, the Oblast was separated from Russia first by one and then by several states (Latvia and Belarus). Finally, the Oblast was marked off with the disintegration of the Soviet Union on 8 December 1991.

Kaliningrad has a unique position in historical, economic and geopolitical terms. This former part of Eastern Prussia, which belongs to the Russian Federation, is $600 \mathrm{~km}$ away from the country. It is closer to Warsaw and Berlin than to Moscow. On the other hand, the Oblast is located relatively close to well-developed regions of Western Europe. The region had the status of a free economic zone in 1992 and has held the status of a special economic zone since 1996.

The present transformation taking place along the Pregola river gives rise to hope, and to a lesser degree, to some concern. Contemporary Kaliningrad, a part of Russia, is undergoing transformation in all spheres of life. Cut off from the world for decades, it is now dynamically making up for lost time, for economic and cultural negligence in the past. An attempt to dissociate from the past has been unsuccessful. We can see it coming back to its roots, though to a different state and ethnic origin (Jasiński 1994).

The development of economic cooperation by neighbouring regions has been initiated by regional and local agreements signed by Polish voivodeships, towns and communes with the Kaliningrad Oblast. The opening up of the Oblast provided an important impetus for developing economic relations - transforming the closed military zone into a free and then a special economic zone. The EU enlargement in 2004 also affected its specific and unique geostrategic location as a part of the Russian Federation lying inside the European Community.

The enlargement of the Schengen Area strongly influenced mutual relations in cross-border cooperation of the neighbouring communities. The introduction of tighter visa and border policies towards Poland's eastern neighbours outside the area was anticipated before the enlargement, including the duty to have a visa, visa prices, and visa restrictions. It was assumed that the major direct effect of the enlargement may be a decrease in the border traffic of individuals, especially in the initial period, as well as social and economic difficulties faced by the cross-border regions. The introduced measures were also expected to hinder small cross-border trade.

The enlargement of the Schengen Area was also expected to influence the effectiveness of eastern policies of the new EU Member States, including Poland, and to weaken their positive offer addressed to the East European societies and governments, thus diminishing the attractiveness of these countries as promoters of the European concept. To limit the severity of the new rules and the losses anticipated as a result of their implementation, national competencies of the EU border states retained certain options for relief and simplifications.

Poland, together with the countries accessing the European Union in 2004, started applying the entire acquis communautaire by the end of 2007 . By 1 September 2007, these states gained access to the Schengen Information System (SIS). Before receiving a visa, every applicant is meticulously checked if they are not wanted or if other Member States have refused them entry.

The inhabitants of the Kaliningrad Oblast, who were entitled to a visa free of charge before 1 June 2007, today must pay 35 euros for a visa, following the agreement concluded on 25 June 2006 in Sochi between the European Union and the Russian Federation. The same fee is binding for Poles applying for Russian visas.

In consequence of introducing fees, the number of visas issued in June 2007 by the Polish Consulate in Kaliningrad fell to one-third compared with the previous month. The falling interest of Kaliningrad inhabitants in travelling to Poland had a clear impact on the local travel bureaus, which recorded a drop in several-day-long trips to Gdańsk by up to $80 \%$.

The decreasing number of passengers travelling by the only railway line between Gdynia and Kaliningrad resulted in limiting the number of carriages from two to one in the middle of 2008, and at the beginning of February 2009 in suspending the connection altogether. The line is to be opened for the summer season. Before Poland's accession to the Schengen Area, 2.5 to 5 
Table. 1 Human border traffic between Poland and the Kaliningrad Oblast in the years 2007-2009.

\begin{tabular}{|c|c|c|c|c|c|c|c|}
\hline \multirow{2}{*}{ Years } & \multirow{2}{*}{ Total } & \multicolumn{3}{|c|}{ Poles } & \multicolumn{3}{c|}{ Foreigners } \\
\cline { 3 - 8 } & & total & from Poland & to Poland & total & from Poland & to Poland \\
\hline 2007 & $2,910,458$ & $1,479,902$ & 727,023 & 752,879 & $1,430,556$ & 718,017 & 712,539 \\
\hline 2008 & $1,915,592$ & $1,128,702$ & 556,251 & 572,451 & 786,890 & 401,070 & 385,820 \\
\hline 2009 & $1,276,339$ & 572,218 & 283,261 & 288,957 & 704,121 & 364,679 & 339,442 \\
\hline
\end{tabular}

Source: Border Guard data (www.strazgraniczna.pl).

thousand persons crossed the border at GronowoMamonovo, as against 1.5 to 2 thousand in 2008. The entire human border traffic, which in 2007 stood at almost 3 million, dropped in 2009 to less than 1.3 million people (Table 1).

In order to stimulate relations with the Kaliningrad Oblast, including economic ones, the Polish Airlines LOT opened a Warsaw-Kaliningrad line on 15 May 2002. LOT airplanes flew even six times a week starting September 2002. The Chopin Airport was a transit point for Kaliningrad inhabitants to many locations in Europe and worldwide. With 1 September 2008, the line was suspended due to the falling number of passengers and loss of profitability.

In October 2007, talks were initiated involving the Commissioner for EU external relations, the Council of the Baltic Sea States and the Russian party during which the EU confirmed its readiness to introduce a special procedure for Polish and Lithuanian local border traffic of residents within a 30-kilometre zone. However, there remains in the Oblast a narrow path, including Kaliningrad itself, not covered by the agreement. In 2010 Poland and Lithuania together with Russia applied to the European Commission to include the entire Kaliningrad Oblast into the local border traffic zone. Perhaps on the grounds of mutual cooperation, the extended area will also refer to the Polish side. Elbląg, which is located $50 \mathrm{~km}$ from the border, is making efforts to qualify as a local border traffic zone.

The introduction of visas between Poland and Russia has hindered and restricted local border trade, which for years was one of the measures mitigating social and economic problems of the cross-border regions. Border markets have lost their vigour and are dying. However, this practice is also undergoing change. The place of Kaliningrad residents is being taken over by Poles, for whom it is easier to cross the border. On the Polish side, there are no longer queues of cars waiting to cross it. On the Russian side, though the number of persons and vehicles has decreased, queues have not disappeared due to the procedures and the officious Russian authorities.

The Schengen rules fortunately have had no impact on economic cooperation with the Kaliningrad Oblast. Trade turnover shows a steady, upward trend. The Russian exports to Poland have mainly shown an increase, $50 \%$ of which being gas followed by oil products, wood, timber, and amber. The Polish products dominating in the import to the Oblast include foodstuffs, household detergents, construction and finishing materials, machines, furniture, footwear, and other consumer goods and plastic products. It is estimated that $20 \%$ of the Polish exports to the Oblast come from the Polish-Russian border region. There are approximately 80 Polish small and medium-sized enterprises operating in the Kaliningrad Oblast. Some of them are seated in Warmia-Mazuria voivodeship.

Polish business investment is minimal; there is practically no direct investment. This situation is connected with the existing border "tightening" the small Kaliningrad Oblast market and big logistic outlays necessary to enter the huge Russian market. Therefore, many big Polish companies enter the market directly. Additionally, Polish investors are limited by infrastructural problems in the Oblast, as well as power and labour shortages.

The spatial development strategy of the Kaliningrad Oblast until 2030 foresees its operation in a competitive environment and its dynamic development in cooperation with the Russian Federation and the Baltic countries. The key objectives set in the document at the federal and the regional level involve identifying social and economic development trends of the Oblast. These require:

- securing a single political, economic and defensive space for the Oblast in Russia, and

- creating conditions for social and economic development of the region comparable to that 
in the countries neighbouring the Kaliningrad Oblast.

To achieve this aim, the main measure for the federal economic policy is to improve the investment climate in the Oblast and upgrade the economy to the level and quality ensuring a sustainable life standard for the Oblast residents comparable to that of residents in the neighbouring states. Priorities for the social and economic development of the Oblast include:

- development of a transport system;

- finding a solution to the problem of power supply independence;

- transformation of the economic structure in the region seeking to develop exports and increase anti-import production stimulated by innovative activities and priorities in the development of the high-technology sector;

- reconstruction of the "amber" industry and the fish-processing complex;

- improvement of the telecommunication infrastructure;

- support for agricultural and food entrepreneurship to assure consumers an adequate level of supplies and independence from supplies from outside the Oblast;

- development of the tourist and recreation sector; and

- further development of scientific research integration processes.

There are also eight key objectives specified for the development of the Kaliningrad Oblast:

1. Integration of the Oblast with the Baltic countries.

2. Development of a balanced system for regional settlement.

3. Improving the quality of life in peripheral, agricultural parts of the Oblast and a diversification of the economy in small towns.

4. Developing an optimal network of landscape, natural-environment and culture-related sites. Developing big integrated nature zones. These areas will contribute to the environmental stability of the region.

5. Development of regional tourist infrastructure and its integration with Baltic Europe tourist infrastructure.

6. Development of an efficient system for protecting the water resources and coastal waters of the Vistula and Curonian Lagoons against man-made hazards.

7. Technological upgrading of transport means, including mass/public transport systems. Reducing the negative impact of transport on the natural environment.

8. Development of power supply systems assuring the Oblast power and environmental security.

Aspects directly related to Poland, indicated in the first objective, involve an inadequate number of border crossings and poor competitiveness of the Oblast ports as compared with the Polish ones. The anticipated measures include dredging a sea fairway to Kaliningrad, developing the existing ports, particularly their ro-ro systems, developing Baltic ferry connections, and modernising the airport.

Also planned is the development of cross-border cooperation in industry, agriculture and the foodstuffs sector, tourism and recreation, environmental protection, and border infrastructure. In particular, this refers to the border-crossing towns of Mamonovo - Braniewo, Bagriationovsk - Bartoszyce, and Oziersk - Gołdap. Other forms of cooperation include:

- international cooperation in the sphere of ecology, tourism and recreation;

- cooperation in protecting cross-border water systems;

- development of Mazurian-Curonian water routes (Great Mazurian Lakes - Mazurian Canal - Łyna - Pregola -Deyma - Polessk Canal - Curonian Lagoon - Baltic);

- development of international communication between Gdańsk and Kaliningrad; and

- separation of the Kaliningrad - Chernyakhovsk - Augustów (Białystok) - Baranovichi - Grodno transport corridor .

The document foresees the development of water sports on, inter alia, the Vistula Lagoon, the Mazurian Canal, and the river Łyna. Under the programme of developing cycling tourism, as part of the international "Baltic Ring" in the Russian part of the Vistula Spit, a cycling centre is planned as well as the construction of bicycle routes. These plans also concern the Vištytis nature reserve.

Kaliningrad, Svetlogorsk and Baltiysk are to develop festival tourism and congress activity. 
The spa functions are to be further developed in Svetlogorsk, Zelenoje, Otradnoye and Pionersky. New spa locations to be established include Yantarny, Donskoye and Primorie, historical and culture-focused tourist centres, as well as "nostalgic" tourism to Kaliningrad, Svetlogorsk, Bagrationovsk, Chernyakhovsk, Gusev, and Sovetsk.

The Kaliningrad tourist-recreation systems are to be included in the international cross-border cooperation network. Water tourism could be established along such water routes as the Augustów Canal (Grodno-Augustów) and the Gdańsk - Elbląg - Kaliningrad - Klaipeda water route. The following are to be included in the international tourist routes leading from the Kaliningrad Oblast: the Augustów Primeval Forest, the Biebrza and Wigry National Parks, the Great Mazurian Lake District with Mikołajki, the Łyna - Pregola water route linking Mazuria with Kaliningrad, and the Mazurian Canal. The Hanseatic League route is to link Gdańsk, Kaliningrad and Riga.

The sixth objective stipulates the development of an efficient system of protection of the water resources and coastal zones of the Vistula Lagoon and the Curonian Lagoon against man-made hazards. The document points to the hyper-eutrophication of the Vistula Lagoon, whose degradation excludes it from performing any economic role and lowers the recreational function of its coast. The major pollution sources of the water basin are the towns of Kaliningrad, Svetly, Mamonovo and Ladushkin. Biogenic compounds (mainly phosphorus and nitrogen) are also discharged to the Lagoon from drainage systems. Industrial and municipal waste takes up more and more space. Approximately $25 \%$ of dung connected with animal production is located in water protection areas of the Pregola, Prochladnoje, Łyna and other Oblast rivers. The document emphasises international responsibility for the quality of the lagoon waters. This means it is necessary to build a sewage treatment plant in, inter alia, Kaliningrad and Mamonovo.

Around the Vistula Lagoon and the mouth of the Elblacg River there are a total of twelve small Polish ports and havens. The biggest Polish sea and river port in this water basin is Elblag. What ended Elblacg's links with the sea, thus degrading it to a peripheral port status, was the situa- tion created by the USSR in 1945 when the state border between Poland and the USSR was redrawn as running across the Vistula Lagoon, from Elblacg and other Lagoon ports through the Strait of Baltiysk to the Baltic Sea. In recent years favourable conditions have appeared for the development of a modern sea port here, operated as a municipal port, managed by the town. Its further development depends on the openness of shipping routes, improved technical condition of facilities, wharfs, port and tourist infrastructure, and on port promotion. It is assumed that the port in Elblacg will ultimately be open to ships of 2.5 thousand GT. The direct hinterland of Elbląg will be the Baltic ports, mainly in the Kaliningrad Oblast (Baltiysk, Kaliningrad, Svetly), as well as small ports in Scandinavia and Germany, and from time to time North Sea ports. The major cargo stream planned in the international turnover of the Elblacg port will embrace goods traded with Kaliningrad. Trade with the Kaliningrad Oblast may embrace a wide range of both exported and imported goods.

The operation of the Elbląg port has depended on political factors since 1945 . The present situation results from the one-sided decision of the USSR, surprisingly and without precedence separating not only the Lagoon water basin but the Vistula Spit itself. Though mutual agreements in force ensure free passage of Polish ships through the Strait of Baltiysk, they remain solely declarations on paper. Ships and yachts under foreign flags as well as Polish vessels and sailing between the Polish and Russian ports around the Vistula Lagoon are prohibited.

Diplomatic talks on the dispute continued since 1991. Thanks to a more lenient attitude to shipping in the Strait of Baltiysk, the Russians opened the Lagoon to ships flying all flags along the entire fairway to Kaliningrad. A shipping line was set up between the Polish and Russian ports in the Lagoon. Such a liberalisation of shipping rules stimulated the ports on both sides. The only remaining restriction involved a ban for ships flying other than the Polish and Russian flags to cross the Russian part of the Lagoon.

However, in 2006 the Russians reinstated rigorous observance of the 1945 treaty and shipping between the ports of both sides came to a standstill. The problem of access to the Polish part of 
the Lagoon became acute, with a detrimental effect on all Polish communes round the Lagoon and of the Kaliningrad Oblast. On September 1 2009, the prime ministers of Poland and Russia signed in Sopot a long-awaited agreement between the government of the Republic of Poland and the government of Russia regarding shipping on the Vistula Lagoon. The actual enforcement of the agreement will be a major factor stimulating the sea port in Elblacg and the tourist sector of the small ports around the Vistula Lagoon. A revival of trade on the Kaliningrad - Elblacg route is connected with the import of about 10 thousand tonnes of coal monthly. The import of aggregate is also planned.

The Vistula Lagoon with the Vistula Spit, the Elbląg Upland Landscape Park and Żuławy Wiślane form a unique natural landscape and environmental complex spreading along the Polish border to the Kaliningrad Oblast. The Vistula Lagoon is a waterfowl sanctuary, while the Vistula Spit flora and the Elblacg Upland Landscape Park feature a multitude of rare plant species and communities. The distinct landscape and environmental assets are also accompanied by many cultural values. However, all those values are not fully protected. While there are two landscape parks here, the Vistula Spit and the Elblacg Upland Landscape Park, they do not ensure sufficient protection of the Lagoon itself. Full protection should be comprehensive, embracing the entire Vistula Spit and Vistula Lagoon together with the coastline, and provided by the Polish and the Kaliningrad side.

On the Russian side of the Vistula Spit, a zoological reserve was created in 1963 called Vislinskaya Kosa. A part from waterfowl and mammals, protection also extended to the unique dunes, woods and beaches, as well as the adjacent sea and Lagoon waters. The reserve, covering an area of $21 \mathrm{~km}^{2}$, ranged across the entire Russian part of the Vistula Spit from the Polish border to the small village of Kosa near the Strait of Baltiysk. Unfortunately, in 2004 the Vislinskaya Kosa preserve suddenly disappeared from all new maps and studies published in Kaliningrad. The Russian side explains the disappearance of the preserve by the expiry of the relevant regulations.

The Kaliningrad Oblast, according to Russian sources, is a region of ecological disaster. In the coastal area there are nine major pollution sources (hot points). Over half of the towns in the Oblast have no effectively operating sewage treatment plants, while those operating do not provide sufficient treatment. The construction of a new sewage treatment plant in Kaliningrad has not been completed. A mechanical treatment plant from the beginning of the previous century is still in operation.

To date, the biggest problem of the Vistula Lagoon is, according to Kaliningrad sources, its hyper-eutrophication. The main polluter is the city of Kaliningrad where untreated, aggressive sewage from half a million of its population flows along an open canal directly to the Lagoon. Ports and oil terminals also discharge oil-contaminated water and industrial waste directly to the Pregola River. To improve the ecological situation of the Lagoon, joint measures are required by both the Polish and the Russian side. Programmes for the social and economic development of the Kaliningrad Oblast provide for solving these environmental problems.

All the Lagoon-based towns in Poland already have their sewage treatment plants. $87 \%$ of those in Warmia-Mazuria voivodeship are equipped with sanitary sewage systems. The basis of international cooperation establishing protected cross-border regions in this part of Europe could be the so called Wigry Declaration signed in 1992 at Wigry by government representatives, local authorities and scientists from Poland, Russia, Lithuania, Latvia, Belarus and Ukraine. The declaration assumes close cooperation of the signatories on the protection of the environment and eco-development.

The entire Vistula Spit is considered to be a nodal region of international importance with its high saturation with unique natural plant communities and natural sanctuaries of European rank. The Vistula Spit Landscape Park, together with a marine zone extending to a depth of 10 metres and a coastal water zone 1 sea mile wide, have been included by HELCOM to the Baltic Sea Protected Areas (BSPA). These are natural environments (or slightly altered by man) of the highest environmental value in the Baltic area.

The Vistula Spit and Lagoon lie in the area of a regional cross-border cooperation structure established in 1998 as the Baltic Euroregion. The 
main objectives of Euroregional cooperation cover, inter alia, the protection and improvement of the environment, development of tourism in crossborder regions, improvement of the efficiency of border traffic, cultural exchange, and care for the common cultural heritage. All premises and conditions show a potential for developing PolishRussian cross-border cooperation in tourism and the environmental protection of the Vistula Spit and Lagoon. The protection system of the Lagoon waters should cover its entire drainage basin on both sides of the border.

On the borderline of Poland, Lithuania and the Kaliningrad Oblast of the Russian Federation lies the Suwałki-Vištytis region featuring such assets as the primeval Romincka Forest. To preserve the exceptional landscape and natural environment of this area, artificially split by the state borders, a trilateral cross-border national park should be established.

Cross-border protected areas should be regions of close cooperation of local authorities and environmental protection offices of Poland and Russia to protect the most valuable areas and promote environmentally friendly forms of tourism and development in line with eco-development principles. The two voivodeships neighbouring on the Oblast, viz. Pomerania and WarmiaMazuria, are interested in cooperating with the exclave. Closer ties, relations and contacts are important for border regions in Poland and the Oblast. Improvement in the ecological situation and infrastructure would provide an opportunity for the development of tourist services.

Potential ecological hazards from the Russian side posed by rapidly developing shipments of oil and oil derivatives can turn to ecological catastrophes caused by disasters of ships (including tankers) and oil rigs, as well as pollution connected with cargo handling and discharging of ballast waters etc. to the Vistula Lagoon and the Gdańsk Bay.

Cross-border environmental hazards affecting Poland can also derive from the operation of the existing military stations, training grounds and warehouses that create a number of environmental problems. The key ecological problem is the storage and treatment of ammunition and obsolete military equipment. Arsenals, stations and warehouses located in a close vicinity of Ka- liningrad city pose a considerable hazard. The direct vulnerability of the city and its residents increases with the appalling technical state of the warehouses, which often do not comply with regulations for ammunition storage.

A hazard that could be an area of future cooperation may also be the drainage systems, built in the times of East Prussia, now split by the state border. The disastrous technical condition of the systems resulting from lack of maintenance and connections with the Russian part is the reason of flooding in the border regions of Bartoszyce and Kętrzyn poviats and on the other side of the border. Many of those areas suffer flooding and bogging not only of farmland, but also of forests and parks.

The Kaliningrad Oblast still has no waste treatment plant. A considerable number of landfills are illegal dumps. Leakage from the dumps pollutes surface waters. To counteract the effects of possible emergencies and eliminate extraordinary hazards, the relevant land and marine services should be better prepared to cope with them than they are today.

The reconstruction of the drainage systems together with canals, gates and culverts should be one of the new forms of cross-border cooperation.

In August 2008 Poland completed the modernisation of the Elblacg - Grzechotki section of the S 22 road; a border crossing was also built in Grzechotki - Mamonovo II. After works have been completed on the Russian side, another border crossing will be opened, so important for both passenger and cargo traffic.

Guidelines for further areas of cross-border cooperation are specified in more detail by the Polish-Russian Council for Cooperation of Regions of the Republic of Poland and the Kaliningrad Oblast of the Russian Federation.

\section{References}

JASIŃSKI J., 1994. Historia Królewca (The history of Królewiec). Książnica Polska, Olsztyn.

Palmowski T. (ed.), 2007. Pogranicze polsko-rosyjskie. Problemy wspótpracy transgranicznej z Obwodem Kaliningradzkim (Polish-Russian border region. Problems in cross-border cooperation with Kaliningrad Oblast). Bernadinum, Gdynia-Pelplin: 7-316. 
Terytorialno-kompleksowy schemat planowania urbanistycznego rozwoju Obwodu Kaliningradzkiego i jego części (Complex territorial urban development planning scheme for the Kaliningrad Oblast and its parts), 2003, Kaliningrad: 7-127.
MoDZeLEWSKI W.T., 2008. Współpraca na pograniczu polskorosyjskim (Cooperation on the Polish-Russian border). In: Żukowski A. (ed.), Polska a Obwód Kaliningradzki Federacji Rosyjskiej. Publishing House Adam Marszałek, Toruń: 159-181. 